\title{
Dependence Bactericidal and Fungicidal Activities from Component Composition of Essential Oils Obtained from some Essential Oil Plants
}

\author{
N.R. Namazov, A.Sh. Safarova, K.F. Bakshaliyeva and P.Z. Muradov* \\ Institute of Microbiology of the NAS of Azerbaijan, Baku \\ *Corresponding author:
}

A B S T R A C T

\section{Keywords}

Essential oil plants, Essential oils, Major and minor components, Composition, Bactericidal and Fungicidal activity

\section{Article Info}

Accepted: 17 November 2018 Available Online: 10 December 2018
In researches were investigat bactericidal and fungicidal activity of essential oils dependent from their component composition and were obtained from some plants included in the flora of Azerbaijan. It became clear that, essential oils which the main component is thymol both individually and in the form of composition is characterized with higher quantitative indicator of bactericidal and fungicidal features. Differentnes of separately components of essential oils used in preparation of compositions to compared with initial indicator was not cause to the reduced of fungicide and bactericide properties.

\section{Introduction}

Continuous increase in the number of the world population within the constantly area increasingly strengthens intervention people to nature and as a result, the bioecological balance directes to the undergo fundamental changes in the direction of global disbalance in the recent years. This is in turn makes certain changes, firstly difficulty in the life activity of all taxonomic groups. The manifestation of these difficulties gives itself up with occurrence of various pathologies among living things and formations of new reproductive, more accurate durable forms and so on $(13,19)$. Preventing of this is considered to be one of the actual research areas of modern biology and medicine sciences. In connection with the solution of these issues needs of living things, including people to the natural products having healing-prophylactic effect at the inconvenient environment conditions is continuously increases. Such properties also has plant products, which based on their biological active ingredients (BAS)(20). To the BAS an example can be shown alkaloids, essential oils, flavonoids, glycosides, coumarins, resin, camellias, etc(11). Among of antifungal medicinal preparations preparations received from 
aromatic or medicinal plants is differs by low toxicity and high activity(1). Therefore, searching for anti-fungal substances within the wild flora is more appropriate and leads to the prospective researches.

One of such substances ie compounds which characterized as a BAS is essential oils (EO) and as a broad pharmacological activity of substance are uses up in various fields of medicine (medicine, cosmetics, etc.) as a features which have a broad spectrum effect (10-12). The component composition of essential oils is different and generally divided into two parts: major and minor. Generally, into composition of essential oils includes about 500 substance (21). The bactericidal and fungicidal influence of the components of essential oils has both scientific and practical importance and currently its clarification is one of the issues that keeps its relevance.

Therefore, the purpose of the presented work were to investigate bactericidal and fungicidal activity of essential oils dependending from major and minor components included in component composition of essential oils which were obtained from some essential oil plants included in the flora of Azerbaijan.

\section{Materials and Methods}

The essential oils used in the research was taken from a number of plants included in the flora of Azerbaijan. Collecting, drying and purchasing essential oils was carried out by based on the methods and approaches used in our previous studies (2-3, 6-7). The composition of the essential oils was determined by the method of LGPC (liquidgas-phase chromatography)(17).

The test cultures used for determination of bactericidal and fungicidal activity were taken to the pure cultures and identified from various sources (soil and plant, as well as clinical materials) based on the methods and approaches adopted in microbiology and mycology (15-16). Identification of microorganisms was carried out according to the determinant $(5,8,18)$ compiled by cultural-morphological and physiological traits.

During determination of bactericidal and fungicidal activity has been used methods based of diameter of the lysis zone (expressed in millimeters) (4), as well as the quantitative indicators of biomass $(\mathrm{g} / \mathrm{l}$ and optical density).

İ research, also were used various compositions of essential oils which the number of major and minor components contained in them theoretically calculated based on the essential oils taken to prepare the composition.

At the time of the research, all the experiments were performed at least 4 times, the results were statistically analyzed (9) and was used information which honesty is no doubt whatsoever.

\section{Results and Discussion}

In researchs firstly were analyzed plants used for obtained essential oil invluded in the cultural and wild flora of Azerbaijan(14) according by its total amount of essential oil as well as major and minor components. From results became clear that, essential oils of plants are differs from each other both by the total amount and the composition components (Table 1).

As seen, a component characterized as major in one plant in others it is either not generally found, or is characterized as a minor component. For the clarify reflection forms of this difference at the bactericidal and fungicidal activities of essential oils obtained 
from plants were prepared various compositions. During preparation compositions as the basis were taken components such as menthol and timol. Based on this information, during research were tried to clarify whether there is any dependence on the major components contained of essential oils with their bactericidal and fungicidal properties. In this direction first were studied both bactericidal and fungicidal properties of essential oils which major and minor components was the same or different and became clear that they shows different quantitative of indicators (tab 2). Thus, the major component of the essential oils of plants such as Nepeta cataria L. and Mentha piperita $L$ is menthol, but at the Achillea millefolium $L$. and Artemisia absinthium $L$. is thymol. Among the components of the essential oils of Achillea millefolium $L$. is also meets menthol. Although during compared their bactericidal or fungicidal properties with each other no apparent dependence but the bactericidal and fungicidal properties of tymol-containing essential oils was higher than menthol (Table 2).

Table.1 General characteristic of essential oils containing in plants used in research

\begin{tabular}{|c|c|c|}
\hline Plants & $\begin{array}{l}\text { The total amount of essential } \\
\text { oils contained in it }(\%)\end{array}$ & $\begin{array}{l}\text { Amount of basic components } \\
\text { contains in essential oils }(\%)\end{array}$ \\
\hline Nepeta cataria $L$. & $2,5-3,0$ & $\begin{array}{l}\text { Menthol- } 98,5 \\
\text { Limenton- } 0,92\end{array}$ \\
\hline Mentha piperita $L$. & $2.5-6,0$ & $\begin{array}{l}\text { Menthol - 89,87 } \\
\text { Menthon - 6,02 }\end{array}$ \\
\hline Achillea millefolium $L$. & $0,75-1,0$ & $\begin{array}{l}\text { Thymol- } 57,24 \\
\text { Menthol }-17,89\end{array}$ \\
\hline Artemisia absinthium $L$. & $0,2-0,5 \%$ & $\begin{array}{l}\text { Thymol- } 30,97 \\
\text { Evcaliptol }-24,13\end{array}$ \\
\hline A.vulgaris $L$ & $0,1-0,3$ & $\begin{array}{l}\text { Iso-thymol }-71,81 \\
\text { Evkaliptol }-17,15\end{array}$ \\
\hline Rosmarinus officinalis $L$. & $1,0-2,4$ & $\begin{array}{l}\alpha \text {-pinen }-30,21 \\
\beta \text {-pinen }-30,14 \\
\text { kamfen }-20,23\end{array}$ \\
\hline Citrus limon (L.) Osbeck & $0,18-0,28$ & $\begin{array}{l}\alpha \text {-limonen }-89,32 \\
\text { sitral }-3,25\end{array}$ \\
\hline Salvia officinalis $L$. & $0,6-1,5$ & $\begin{array}{c}\text { Tsineol - } 15 \\
\alpha \text {-tuyon - } 10 \\
\beta \text {-tuyon -8 } \\
\text { D- } \alpha \text {-pinen- } 7\end{array}$ \\
\hline Alhagi maurorum Medik & $0,26-0,30$ & $\begin{array}{c}\text { Drimenol - 23,22 } \\
\text { 9-Octylheptadecan - 9,17 }\end{array}$ \\
\hline P.silvesgtris $L$ & $0,32-0,48$ & $\begin{array}{c}\alpha \text {-pinen }-27,9 \\
\alpha \text {-kadinen }-9,51\end{array}$ \\
\hline Ocimum basilicum $L$. & $0,52-0,64$ & $\begin{array}{l}\text { Eugenol }-36,1 \\
\text { Phytol }-30,8\end{array}$ \\
\hline $\begin{array}{l}\text { Valeriana officinalis L. S. } \\
\text { L. }\end{array}$ & $0,32-0,85$ & $\begin{array}{c}\text { Bronilasetat }-25,36 \\
\text { Qvayol }-24,12 \\
\text { İzovalerian turşusu }-12,14\end{array}$ \\
\hline
\end{tabular}


Table.2 Bactericidal and fungicidal activity of plants which major elements of the composition of essential oils are similar and distinctive

\begin{tabular}{|c|c|c|c|}
\hline \multirow[t]{2}{*}{ Composition } & \multirow[t]{2}{*}{ Test cultures } & \multicolumn{2}{|c|}{ Activity } \\
\hline & & $\begin{array}{c}\text { By the output of } \\
\text { biomass (\% according } \\
\text { to control) }\end{array}$ & $\begin{array}{l}\text { By the diameter } \\
\text { of the lysis zone } \\
(\mathrm{mm})\end{array}$ \\
\hline \multirow{10}{*}{$\begin{array}{l}\text { Nepeta cataria } L \text {. } \\
\text { Menthol- 98,5 } \\
\text { Limenton- } 0,92\end{array}$} & Bac.subtilus & 6,4 & 20 \\
\hline & St.aureus & 6,2 & 21 \\
\hline & Ps.aureginoza & 6,5 & 19 \\
\hline & Ech. coli & 5,9 & 22 \\
\hline & Candida alpicans & 2,1 & 28 \\
\hline & Fuzarium oxysporium & 0 & 32 \\
\hline & Aspergillus niger & 2,0 & 22 \\
\hline & A.ochraseus & 2,3 & 21 \\
\hline & Penicillium citrinum & 0 & 32 \\
\hline & Penicillium cyclopium & 0 & 34 \\
\hline \multirow{10}{*}{$\begin{array}{l}\text { Achillea millefolium L. } \\
\text { Thymol- } 57,24 \\
\text { Menthol }-17,89\end{array}$} & Bac.subtilus & 3,4 & 22 \\
\hline & St.aureus & 3,2 & 23 \\
\hline & Ps.aureginoza & 3,5 & 21 \\
\hline & Ech. coli & 2,9 & 24 \\
\hline & Candida alpicans & 0 & 32 \\
\hline & Fuzarium oxysporium & 1,8 & 23 \\
\hline & Aspergillus niger & 1,0 & 25 \\
\hline & A.ochraseus & 0 & 29 \\
\hline & Penicillium citrinum & 0 & 30 \\
\hline & Penicillium cyclopium & 0 & 32 \\
\hline \multirow{10}{*}{$\begin{array}{l}\text { Artemisia absinthium L. } \\
\text { Thymol- } 30,97 \\
\text { Evcaliptol }-24,13\end{array}$} & Bac.subtilus & 2,4 & 25 \\
\hline & St.aureus & 2,2 & 26 \\
\hline & Ps.aureginoza & 2,5 & 24 \\
\hline & Ech. coli & 1,9 & 27 \\
\hline & Candida alpicans & 0 & 33 \\
\hline & Fuzarium oxysporium & 0 & 28 \\
\hline & Aspergillus niger & 0 & 30 \\
\hline & A.ochraseus & 0 & 32 \\
\hline & Penicillium citrinum & 0 & 34 \\
\hline & Penicillium cyclopium & 0 & 37 \\
\hline
\end{tabular}


Table.3 Bactericidal and fungicidal properties of compositions prepared from essential oils which major components is differs from each other

\begin{tabular}{|c|c|c|c|}
\hline \multirow[t]{2}{*}{ Composition } & \multirow[t]{2}{*}{ Test cultures } & \multicolumn{2}{|c|}{ Activity } \\
\hline & & $\begin{array}{l}\text { By the output of biomass } \\
\text { (according to control)\%) }\end{array}$ & $\begin{array}{l}\text { According to the diameter of } \\
\text { the lysis zone }(\mathrm{mm})\end{array}$ \\
\hline \multirow{10}{*}{$\begin{array}{c}\text { Nepeta cataria } L . / \\
\text { Salvia officinalis } L \\
1: 1\end{array}$} & Bac.subtilus & 5,4 & 21 \\
\hline & St.aureus & 5,2 & 22 \\
\hline & Ps.aureginoza & 5,5 & 20 \\
\hline & Ech. coli & 4,9 & 23 \\
\hline & Candida alpicans & 1,7 & 29 \\
\hline & Fuzarium oxysporium & 0 & 31 \\
\hline & Aspergillus niger & 1,5 & 23 \\
\hline & A.ochraseus & 2,0 & 23 \\
\hline & Penicillium citrinum & 0 & 29 \\
\hline & Penicillium cyclopium & 0 & 30 \\
\hline \multirow{10}{*}{$\begin{array}{c}\text { Achillea } \\
\text { millefolium L./ Salvia } \\
\text { officinalis } L . \\
1: 1\end{array}$} & Bac.subtilus & 2,4 & 24 \\
\hline & St.aureus & 2,2 & 25 \\
\hline & Ps.aureginoza & 2,5 & 23 \\
\hline & Ech. coli & 1,9 & 26 \\
\hline & Candida alpicans & 0 & 34 \\
\hline & Fuzarium oxysporium & 1,1 & 25 \\
\hline & Aspergillus niger & 0,5 & 27 \\
\hline & A.ochraseus & 0 & 30 \\
\hline & Penicillium citrinum & 0 & 31 \\
\hline & Penicillium cyclopium & 0 & 33 \\
\hline \multirow{10}{*}{$\begin{array}{c}\text { Artemisia } \\
\text { absinthium } L . \\
\text { / Salvia officinalis } L \\
1: 1\end{array}$} & Bac.subtilus & 1,1 & 31 \\
\hline & St.aureus & 1,2 & 32 \\
\hline & Ps.aureginoza & 1,3 & 29 \\
\hline & Ech. coli & 1,0 & 31 \\
\hline & Candida alpicans & 0 & 34 \\
\hline & Fuzarium oxysporium & 0 & 31 \\
\hline & Aspergillus niger & 0 & 33 \\
\hline & A.ochraseus & 0 & 34 \\
\hline & Penicillium citrinum & 0 & 36 \\
\hline & Penicillium cyclopium & 0 & 39 \\
\hline \multirow{10}{*}{$\begin{array}{c}\text { Artemisia } \\
\text { absinthium L. } \\
\text { / Alhagi maurorum } \\
\text { Medik } \\
1: 1\end{array}$} & Bac.subtilus & 1,9 & 29 \\
\hline & St.aureus & 2,0 & 30 \\
\hline & Ps.aureginoza & 2,3 & 27 \\
\hline & Ech. coli & 2,0 & 29 \\
\hline & Candida alpicans & 0 & 31 \\
\hline & Fuzarium oxysporium & 0 & 29 \\
\hline & Aspergillus niger & 0 & 31 \\
\hline & A.ochraseus & 0 & 32 \\
\hline & Penicillium citrinum & 0 & 33 \\
\hline & Penicillium cyclopium & 0 & 36 \\
\hline
\end{tabular}

Accurate information about bactericidal and fungicidal activity of the major components of essential oils of this or those plant can say after obtained separate components of essential oils in pure form. Although from this results can be noted thymol containing 
essential oils are characterized with more higher bactericidal and fungicidal features. As confirmation of last opinion can also be based the information below. To the obtained this informations were investigated bacterisid and fungisid propeties of compositions prepated with combined essential oils contains thymol and menthol, and other essential oils which is not contains this components. The obtained results are given in table 3 . As seen, in spite the activity degree of separately components of compositions sometimes is changeable butin some variants observes rise effect that is, the bactericidal and fungicidal properties of the composition are rising. This increas effects is rises depending from the sours of component composition and biologcal features of cultures and gives itself on the conpositions compored from essential oils which major component is thymol (tab. 3). As seen, bactericidal and fungicidal activity of any ratio of composition prepared from the essential oils of Achillea millefolium $L$ and A. Artemisia absinthium $L$. were higher than they were shown separately and the highest effect was observed in the composition of Artemisia absinthium L. and Salvia officinalis $L$. in the ratio of 1:1. Both bactericidal and fungicidal activity (calculated on the amount of timol contained in the medium) of others composition(Nepeta cataria L./Rosmarinus officinalis L., Nepeta cataria L./Citrus limon (L.), Nepeta cataria L./ Valeriana officinalis L., Nepeta cataria L./Alhagi maurorum Medik, Achillea millefolium L./Citrus limon (L.), Achillea millefolium L./Rosmarinus officinalis L., Achillea millefolium L./Alhagi maurorum Medik, Achillea millefolium L./ Valeriana officinalis L., Artemisia absinthium L./Rosmarinus officinalis L, Artemisia absinthium L./Citrus limon (L.), Artemisia absinthium L./Valeriana officinalis $L$., Artemisia absinthium L./Ocimum basilicum L) prepared based on essential oils contained thymol are higher than others. Interestingly, none of the composition were not observed reduction bactericidal or fungicidal activity to the compared with initially.
Thus, from the carried out of researchs became clear that, bactericidal and fungicidal activity of essential oils obtained from a number of plants included in the flora of Azerbaijan depends from their component composition and the bactericidal and fungicidal properties of essential oils major component is thymol, both individually and in form of composition is characterized by higher quantitative indicators. This case gives itself during used compasition of Artemisia absinthium $L$ and Salvia officinalis $L$ in ratio of 1:1. Difference major and minor components of essential oils used in the preparation of compositions compared to the initially is not observed decline at the bactericidal and fungicidal activities.

\section{References}

1. Babar Ali, Naser Ali Al-Wabel, Saiba Shams, Aftab Ahamad, Shah Alam Khan, Firoz Anwar. 2015. Essential oils used in aromatherapy: A systemic review. Asian Pacific Journal of Tropical Biomedicine., 5, 8:601-611

2. Bakshaliyeva K.F., İsmayılova G.E., Bayramova F.V., Muradov P.Z. 2018. Influence of compositions based on white naphthalene and essential oils on growth of bacteria and fungi. Scientific works of the Institute of Microbiology of ANAS, 16,1:37-41

3. Bakshaliyeva K.F., Muradov P.Z., İsmayilova G.E., Namazov N.R., Jabrailzade S.M. 2017. Fungicidal activity of some medicinal plants of the flora of Azerbaijan. Modern Mycology in Russia., 7:208-209.

4. Egorov N.S. 1995. Guide to practical training in microbiology. Training Allowance 3rd ed., revised and additional M.: Publishing House MSU, 224

5. http://www.mycobank.org/MycoTaxo.as $\mathrm{px}$

6. İsmayılova G.E., Namazov N.R., Bakhshaliyeva K.F., Yusifova M.R., Rahimova M.M. 2018. Fungisid features 
of the compositions prepared from the various sources of components. Jokull Journal, 68,7:21-26

7. Jalilova S.Kh., Yusifova.M.R., Bahsaliyeva K.F., Namazov N.R. 2017. The fungicide feature of some essential oil plants used in the folk medicine. REVISTA KASMERA (Venuzuella), 45(1): 43-47.

8. Kirk P. M., Stalpers J.A. 2008. Dictionary of the fungi, 10th edn. CABI publishing / P. M. Kirk, P. F. Cannon, D. W. Minter.- Wallingford(UK), 600.

9. Kobzar A.İ. 2006. Applied mathematical statistics. M.: PHYSMATHLIT, 816.

10. Kondratyuk T.A., Zikova İ.D. 2013. Essential oils of spicy-flavoring plants // Successes of modern natural science, 9:135-139;

11. Kumar S., Pandey A.K. 2013. Chemistry and biological activities of flavonoids: an overview. Sci. World J., 13:1-16.

12. Lapkina E.Z., Zakharova T.K., Tirranen L.S. 2017. Component composition of the essential oil of wormwood (Artemisia salsoloides Willd) and its antimicrobial properties //Chemistry of plant materials, 3:157-162

13. Marfenina O.E. 2005. Anthropogenic ecology of soil fungi. M.: Medicine for all, 195.

14. Mehdiyeva N.P. 2011. Biodiversity of medical flora of Azerbaijan. Baku: "Letterpress", 186.
15. Methods of experimental mycology. 1982. Edited by. Bilai V.I. Kiev: Naukova Dumka, 500.

16. Netrusov A.İ., Egorova M.A., Zakharchuk L.M. and Oth. 2005. Practical work on microbiology. M.: Publishing Center "Academy", 608.

17. Pisarev D.İ., Novikov O.O. 2012. Methods for the isolation and analysis of essential oils. Scientific Gazette BelSU, ser. Medicine, Pharmacy, 10:25.

18. Samson R.A., Pitt J.I. Integration of modern taxonomic methods for Penicillium and Aspergillus classification. Amsterdam: Harwood Publishers, 2000, 510p.

19. Shkarin V.V., Saperkin N.V. Epidemiology of opportunistic mycoses. // Bulletin of dermatology and venereology 2017, v. 3, p. 21-31.

20. Yarosh A.M., Tonkovtseva V.V., Boroda T.V., Serobaba L.A., Seredina O.S. et al., Essential oil composition of Lavandula officinalis and Juniperus virginiana and its effect on human nervous system // Works of the State Nitit. Botan. Gard., 2015, v.141, p.79-85

21. Zikova İ.D., Efremov A. A. Component composition of essential oils of coniferous plants of Siberia: monograph. Krasnoyarsk: Sib. feder. un-t, 2013, p 133.

\section{How to cite this article:}

Namazov, N.R., A.Sh. Safarova, K.F. Bakshaliyeva and Muradov, P.Z. 2018. Dependence Bactericidal and Fungicidal Activities from Component Composition of Essential Oils Obtained from some Essential Oil Plants. Int.J.Curr.Microbiol.App.Sci. 7(12): 2406-2410. doi: https://doi.org/10.20546/ijcmas.2018.712.273 